\title{
Poemas Centro-oestinos, Kalungarias e sobre os Povos da Terra
}

Georgia Marques

\section{Resumo}

O objetivo é apresentar poemas centro-oestinos escritos pela poética da GeoPoesia, que, com sua escrita da Terra, descreve em fotos e geo-grafias experiências verdes e ricas tais quais as montanhas de Minas Gerais, que desenham corpos negros e dourados como os que se banham nas águas quentes da Bahia, e gelados como os pés que tocam as mais profundas águas dos rios do estado de Goiás. Há, nessa poesia, relatos da vida pública envolta pelas Asas da Capital Federal que não tem mar, mas sobrevive em lagos e lados a céu aberto, mimeticamente pincelados pelas poeiras do Cerrado, do tempo e do vento, da memória viva composta por formas, cores e expressões arquitetônicas: símbolos e ideais que marcam a vida de todo o povo e fazem história nos conflitos burocráticos e civis sobre este território.

Palavras-chave: Poemas centro-oestinos - Kalungaria - Povos da Terra Geopoesia. 


\section{Mulheres do tambor}

Qual sua origem?

Qual sua ascendência?

Sua descendência?

Sinta seu coração pulsar

na cadência do toque!

(A Nãnan Matos.)

\section{Bicicletaria}

Se eu tivesse uma bike, eu muito bicicletaria

Ava-canoaria

terras Xavantes

avante adentraríamos

Matas e cílio correríamos

O cheiro forte de nossas

avós ciganas,

baianas e candangas

farejaríamos

Fadas encantadas, deusas que abrem caminhos

com a Luz Del Fuego

iluminam estradas

Juntas habitaríamos

uma ilha chamada Brasil

Braz-ilha.

(A Bic Prado.) 


\section{Tele-visão}

Me oriento pela tele-visão visão espacial, meu espaço descompassado sideral.

\section{Rodas e vento}

Rosas do vento

Rosas ao vento

Rodas de Exu

trancas, amarras

alentos

caminhos

proteção

intento

coração

força

humanidade

ruas, almas

vagas, abra

ocupe, perdure

apure, ame

\section{Prende e passa}

Tudo isso vai passar

deixe o ar entrar

penetrar, arrancar

sair e voar

deixe passar o ar. 


\section{Pedágio}

Sua boca tinha cheiro de rosa,

fiquei preso naquele sorriso,

uma pena que a cor da cédula

e seu cheiro podre nos separava,

eu continuei na estrada a procurá-la.

Quanto vale a democracia?

Quanto vale uma boca vazia?

Quanto vale a cidadania?

Afinal, o que é toda essa patifaria?

Hora marcada, encontros

desencontrados, sonhos cortados, podres

iluminados, onde estão meus achados? Perdidos.

É preciso pagar o pedágio para encontrá-los.

(A Wélcio de Toledo e as Minas Gerais, nas Estradas Reais.)

\section{9 de abril}

Não muito longe daqui

estão cavando nossas terras

tirando nosso povo do lar

cimentando nossos corações

tentando calar nossa voz

estão estes à nos estuprar

dói meu ventre de mãe

dói minha alma de filha

dói meu canto de pai

silenciam meu pedido por socorro

arrancam minhas raízes fonte d'água

preciso semear para me curar

cor do urucum, cor

do sangue que corre

e que sai de mim, cor 
da aurora e do arco, cor

quem não tem no coração

tem nas mãos, cor

da íris, cor de Ísis

Terra.

(A Valdelice Veron.)

\section{Cobra Coral}

Quando eu era criança, cobras corais abriam meus caminhos, eu nadava com elas nos rios, minha mãe preta muito me carregou no colo, cuidou e deu amor.

\section{Grito}

Você pode me escutar quando não vê meu rosto?

Eu grito, sou o grito agito e não evito, entro, no conflito, assim existo, reexisto! Poeta, porreta!

parei de viver da espera vivo no pulso que pulsa impulsiona e transforma tudo em luz, tudo em voz

Tudo em ar, tudo em arte tudo é céu, tudo é escuridão a imensidão do céu escuro dá vida à estrela onde tudo é poeira, tudo é poesia. 
Tudo tem mulher, tudo tem

Terra, tudo é água, tudo tem

forma tudo em flor de Maria.

Tudo tem Marina.

(A Marina Mara e Nirlene Maria.)

\section{Kalungaria}

Eu sonhava com a vida, mas só morte via naquele vão, cheio de almas desencarnadas sob um céu de estrelas cadentes com as mãos atadas, meus pés batiam meu coração pulsava e a água ardente curvava.

Agradeci minha grande mãe por ajudar na travessia da estrada, caminhada sofrida à beira do abismo não olhei para baixo nem para os lados, então me senti no paraíso.

Meu avô, um preto velho sabendo de minha chegada encomendou várias noites de festa a poeira da dança subia após a reza candeias acenderam aquecendo meu coração na escuridão daquele vão. Almas Vão-se Amar.

\section{Viagem}

A janela que levou meu pai parecia uma mandala de exposição no metrô a arte era um pedaço de carne pendurada 
mecanização da manufatura

tear e pesadelo, holocausto na lona

ventos e recados enviados pelos correios

pinico embaixo da cama, água de aranhas

desenho no arroz, falta vontade para comer

aprendizado nas latas, flores da montanha

Alto Paraíso, morte e despedida

de uma pessoa em vida, são os cantos da natureza

canto do homem na natureza é cacto sem flor

foto da urbanização, irmãos no trenzinho

nuvens movendo as árvores da diversidade

simplicidade da cabaça, cabeça dos peixes

animais e risos, folhas de coqueiro

galinha-d'angola

pé descalço

tambor

amor.

(A minha avó baiana.)

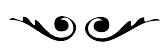

Georgia Marques é graduanda em Pedagogia pela Universidade de Brasília.

georgiaaacm@gmail.com 